\title{
Kekerasan Dalam Rumah Tangga dalam Perspektif Islam
}

\author{
Nur Rofiah \\ UIN Syarif Hidayatullah Jakarta DPK Institut PTIQ \\ Jl. Batan I No. 2 Lebak Bulus Cilandak Jakarta Selatan, Jakarta, Indonesia. \\ E-mail: nur.rofiah@uinjkt.ac.id
}

\begin{abstract}
Domestic violence is often understood to refer only to physical abuse. In fact, domestic violence is related to any violence occurred in domestic life that includes: physical, sexual, and psychological violence. It also related to abandonment and threat in domestic life. Many cases of domestic violence are unreported by the victims because they considered domestic violence as a private matter. This article attempts to explore domestic violence in Islamic perspective. This article shows that domestic violence occurred as a result of an asymmetrical relationship between spouses in a marital relationship. To avoid domestic violence, the couple should attempt to build a harmonious relationship (sakinah) based on equality between the spouse.
\end{abstract}

Keywords:

Domestic violence; female; gender; Islam; violence.

\begin{abstract}
Abstrak
Kata kekerasan dalam istilah KDRT seringkali dipahami masyarakat umum terbatas pada kekerasan fisik. Padahal bentuk kekerasan dalam KDRT itu bermacam-macam diantaranya adalah: fisik, seksual, psikologis, dan/atau penelantaran rumah tangga termasuk ancaman untuk melakukan perbuatan, pemaksaan, atau perampasan kemerdekaan secara melawan hukum dalam lingkup rumah tangga. KDRT kerap tidak terdeteksi oleh tetangga dekat apalagi negara karena terjadinya di ruang tertutup. Hal ini menyebabkan jumlah korban KDRT yang sesungguhnya sulit didapatkan. Tulisan ini berusaha untuk memaparkan KDRT dalam perspektif Islam. Artikel ini menunjukkan bahwa KDRT muncul akibat relasi yang tidak setara antara pelaku dan korban dalam sebuah rumah tangga. Budaya patriarkhi juga turut andil sebagai pemicu kekerasan dalam rumah tangga. Salah satu strategi untuk menghindari KDRT adalah dengan membangun keluarga sakinah dalam perspektif kesetaraan.
\end{abstract}

\section{Kata Kunci:}

Gender; Islam; kekerasan rumah tangga; Kekerasan; perempuan.

DOI: $10.15575 / \mathrm{jw} . \mathrm{v} 2 \mathrm{i} 1.829$

Received: June 2016; Accepted: June 2017; Published: June 2017

\section{A. PENDAHULUAN}

Rumah tangga seharusnya menjadi tempat yang menyediakan ketentraman (sakinah) bagi setiap orang. Namun ada prilaku kekerasan yang sering kali terjadi, dan menyebabkan ranah yang paling privat di sebuah masyarakat ini justru berdampak bagi pertumbuhan dan perkembangan anak tidak berjalan maksimal karena diliputi dengan rasa ketakutan dan khawatir berkepanjangan, hingga luka fisik, ancaman pembunuhan sebagaimana penuturan seorang ustadzah di bawah ini, bahkan kematian itu sendiri.
Pada suatu malam, kami berada di kamar. Aku tanya sikapnya yang seperti itu apa ada hubungannya dengan TTK. Dia marah dan ambil pisau celurit. Aku menjerit-jerit minta tolong. Lalu dikalungkannya celurit itu ke leherku sambil mengancam, "Kalau kamu tanya-tanya lagi soal TTK, kamu saya bunuh. ${ }^{1}$

${ }^{1}$ Testimoni ustadzah RM, salah seorang perempuan korban KDRT yang menjadi narasumber penelitian ALIMAT tentang realitas kehidupan perempuan dalam kehidupan keluarga yang dikompilasi dalam Alimat, 
Fenomena diatas adalah salah satu gambaran kekerasan dalam rumah tangga (KDRT), sebuah fenomena yang hampir bisa dijumpai di setiap rumah tangga dengan intensitas dan kadar yang berbeda-beda. Ada rumah tangga yang sangat jarang mengalami KDRT, namun ada pula sebuah rumah tangga yang setiap hari diwarnai KDRT. Ada yang mengalami kekerasan verbal seperti bentakan dan kata-kata yang tidak menyenangkan, namun ada pula yang mengalaminya secara berlapis. Misalnya kekerasan verbal, fisik, psikhis, dan ekonomi, sosial, seksual, bahkan kekerasan spiritual.

Di sisi lain, Islam menegaskan bahwa tujuan berumah tangga adalah terjalinnya rasa kasih sayang dan terpenuhinya ketentraman (sakinah) dalam rumah tangga. Oleh karena itu Islam menolak tegas KDRT, meskipun kadang melakukan kompromi karena beberapa bentuk KDRT tidak bisa dihapuskan seketika. Dengan penelusuran dokumen dan data-data kepustakaan, penelitian ini berusaha memaparkan dan mengungkap fakta kekerasan dalam rumah tangga (KDRT) yang berakar pada ideologi patriarki, dan menunjukkan bagaimana Islam menolak nilai patriarkhi yang menjadi akar kekerasan terhadap perempuan, baik di masa pewahyuan maupun sekarang, yang bisa terjadi di ruang publik maupun rumah tangga.

\section{B. HASIL DAN PEMBAHASAN \\ 1. Mengenal Kekerasan Dalam Rumah Tangga}

Kata kekerasan dalam istilah KDRT seringkali dipahami masyarakat umum terbatas kekerasan fisik. Padahal bentuk kekerasan dalam KDRT itu bermacam-macam sebagaimana tertuang dalam UU No. 23 Tahun 2004 tentang Penghapusan Kekerasan Dalam Rumah Tangga (UU PKDRT) Pasal 1 adalah sebagai berikut: Kekerasan dalam rumah tangga adalah setiap perbuatan terhadap seseorang terutama perempuan, yang berakibat timbulnya kesengsaraan atau penderitaan

Kisah Perjuangan Perempuan Dalam KeluargaAlimat, 2012 (Jakarta: Alimat, 2012), 22. secara fisik, seksual, psikologis, dan/atau penelantaran rumah tangga termasuk ancaman untuk melakukan perbuatan, pemaksaan, atau perampasan kemerdekaan secara melawan hukum dalam lingkup rumah tangga.

Berdasarkan undang-undang tersebut, maka kekerasan dalam rumah tangga yang ada empat bentuk yaitu kekerasan fisik misalnya memukul, menendang, melukai, hingga membunuh, kekerasan seksual mulai dari pelecehan seksual misalnya menyentuh payudara, pantat, dan anggota tubuh lainnya hingga pemerkosaan (termasuk kekerasan seksual dan pemerkosaan incest), kekerasan psikologis misalnya perselingkuhan, dan kekerasan ekonomi yang dapat beruba penelantaran rumah tangga. Keempat bentuk tersebut adalah pelanggaran yang dapat diproses secara hukum. Kekerasan dalam rumah tangga juga bisa berupa kekerasan verbal misalnya membentak dan menghina, kekerasan sosial misalnya larangan bertemu saudara dan bergaul dengan tetangga, kekerasan spiritual misalnya larangan untuk menjalankan ritual agama sesuai dengan keyakinan atau mdzhabnya.

KDRT hanya berlaku dalam perkawinan atau rumah tangga hasil perkawinan yang diakui oleh negara. Oleh karena itu, sebuah kekerasan hanya bisa diproses secara hukum negara jika perkawinannya pun sah menurut negara, yakni sesuai dengan agama masingmasing dan dicatatkan dalam catatan negara yang ditandai dengan adanya buku nikah resmi dengan nomer registrasi tercatat. Ada pula istilah kekerasan yang meliputi namun tidak terbpeg pada KDRT, yaitu kekerasan ranah personal (RP) yaitu kekerasan di mana pelakunya adalah orang yang memiliki hubungan darah (ayah, kakak, adik, paman, kakek), kekerabatan, perkawinan (suami), maupun relasi intim (pacaran) dengan korban. ${ }^{2}$

\footnotetext{
2 "Lembar Fakta Catatan Tahunan (Catahu) Komnas Perempuan Tahun 2014, , Kekerasan Terhadap Perempuan: Negara Segera Putus Impunitas Pelaku" (Jakarta, 2015), http://www.komnasperempuan.or.id/wp-content/uploads/2015/03/Lembar-Fakta-
} 
KDRT kerap tidak terdeteksi oleh tetangga dekat apalagi negara karena terjadinya di ruang tertutup. Hal ini menyebabkan jumlah korban KDRT yang sesungguhnya sulit didapatkan. Namun demikian, sejak lembagalembaga yang melakukan layanan korban KDRT berkembang dan payung hukum yang melindungi hak korban disahkan, korban KDRT mulai bisa mencari dan mendapatkan pertolongan.

Komisi Nasional anti Kekerasan terhadap Perempuan (Komnas Perempuan) mencatat angka kasus KDRT atau kekerasan ranah personal (RP) yang fluktuatif sepanjang satu dasawarsa (2004-2013) seperti dalam tabel 1:

Tabel.1 Angka Kasus KDRT/RP 2004-2011

\begin{tabular}{lr}
\hline Tahun & Jumlah KDRT/RP \\
\hline 2004 & 4.310 \\
\hline 2005 & 16.615 \\
\hline 2006 & 16.709 \\
\hline 2007 & 19.253 \\
\hline 2008 & 49.537 \\
\hline 2009 & 136.849 \\
\hline 2010 & 101.128 \\
\hline 2011 & 113.878 \\
\hline 2012 & 8.315 \\
\hline 2013 & 11.719 \\
\hline
\end{tabular}

Salah satu alasan fluktuasi jumlah kasus KDRT/ RP adalah perbedaan jumlah sumber penumpulan data per tahun sebagaimana dijelaskan oleh Komnas Perempuan. Data tahun 2004-2008 bersumber dari jumlah kasus yang dilaporkan pengada layanan dan Komnas Perempuan. Sumber data untuk tahun 20092011 bersumber diperoleh dari laporan mitra pengadalayanan dan data dari pengadilan agama. Tahun 2012-2013 berasal dari pengadalayanan dan Komnas Perempuan. ${ }^{3}$ Fluktuasi

Catatan-Tahunan-CATAHU-Komnas-PerempuanTahun-2014.pdf pada Senin 24 Maret 2015.

3 "Lembar Fakta, Satu Dasawarsa UU PKDRT: Perempuan Korban Belum Mendapat Perlindungan Komprehensif' (Jakarta, 2014), https:/www.komnasperempuan.go.id/wp-content/uploads/2014/09/LEMBAR-FAKTA-Satu-Dasawarsa-UU-PKDRT- jumlah kasus sebagaimana jumlah kasusnya juga tidak selalu menunjukkan situasi yang sesugguhnya terjadi di masyarakat. Melihat terbatasnya lembaga penyedialayanan dan terbatasnya akses korban KDRT/RP pada penyedialayanan yang ada, maka dapat dipastikan jumlah kasus KDRT/RP yang sesungguhnya jauh lebih banyak. Hal ini berarti bahwa kasus KDRT/ RP di masyarakat bisa jadi sesungguhnya naik, meskipun data yang tercatat turun. Paling tidak data ini cukup akurat untuk menunjukkan dua hal, yaitu adanya kasus KDRT/ RP yang banyak di masyarakat dan adanya kemauan masyarakat untuk mulai mencari pertolongan untuk mengatasi KDRT yang menimpa mereka.

Komnas Perempuan yang berdiri pada tanggal 15 Oktober 1998 ini juga mencatat jumlah kasus KDRT atau RP di tahun 2014 dalam Catatan Tahunan 2015 Komnas Perempuan, sebagai berikut:

1. Sebanyak 8.626 kasus di ranah personal, 59\% atau 5.102 kasus berupa kekerasan terhadap istri, $21 \%$ atau 1.748 kasus kekerasan dalam pacaran, $10 \%$ atau 843 kasus kekerasan terhadap anak perempuan, 9\% atau 750 kasus kekerasan dalam relasi personal lain, $1 \%$ atau 63 kasus kekerasan dari mantan pacar, $0,7 \%$ atau 53 kasus kekerasan dari mantan suami, dan $0,4 \%$ atau 31 kasus kekerasan terhadap pekerja rumah tangga.

2. Kasus kekerasan fisik masih menempati urutan tertinggi pada jenis tindak kekerasan dalam ranah personal di tahun 2014, yaitu mencapai 3.410 (40\%), diikuti posisi kedua kekerasan psikis sebesar 2.444 (28\%), kekerasan seksual 2.274 kasus (26\%) dan kekerasan ekonomi 496 kasus (6\%). Urutan di atas sama dengan data tahun 2013.

3. Mayoritas rentang usia perempuan korban di ranah personal adalah 25-40 tahun, menyusul setelahnya di usia 13-18 tahun, kemudian di usia 19-24 tahun. Ini berarti

Perempuan-Korban-Belum-Mendapat-PerlindunganKomprehensif.pdf. 
bahwa kekerasan tertinggi terjadi pada usia nikah (25-40 tahun). ${ }^{4}$

Meningkatnya kesadaran masyarakat yang menjadi korban KDRT dapat pula ditunjukkan oleh data gugat cerai (cerai atas inisiatif istri) yang memiliki kecenderungan meningkat dan jumlahnya lebih banyak daripada angka cerai talak (cerai atas inisiatif suami). Dirjen Bimas Islam Kemenag RI menyebutkan bahwa Ditjen Bimas Islam sudah mencatat jumlah cerai gugat yang hampir dua kali lipat dari cerai talak yang terjadi sejak akhir 2006 hingga akhir 2007, yaitu total perceraian sebanyak 148.738 peristiwa. Berdasarkan data Balitbang Kementerian Agama, bahwa dari angka perceraian tersebut, lebih dari $70 \%$ merupakan cerai gugat atau pihak perempuanlah yang menggugat cerai. $^{5}$ Data Badan Peradilan Agama (Badilag) juga menunjukkan bahwa pada tahun 2012 angka cerai gugat dua kali lipat lebih dibandingkan dengan cerai talak, yakni 107.780 kasus cerai talak dan 238.666 cerai gugat. $^{6}$

Keterkaitan meningkatnya kasus KDRT yang terlapor di satu sisi, dan fenomena meningkatnya angka cerai gugat sehingga menjadi lebih tinggi daripada angka cerai talak di berbagai tempat adalah sangat erat. Salah satu hal yang bisa disimpulkan dari dua jenis data ini adalah bahwasanya KDRT membuat rapuh tali perkawinan sehingga mudah putus dan menyebabkan rumah tangga rentan berantakan. Oleh karena itu, selama institusi perkawinan dan keluarga dipandang penting oleh sebuah masyarakat, maka penting pula kesadaran masyarakat untuk menolak dirinya

\footnotetext{
4 “Lembar Fakta, Satu Dasawarsa UU PKDRT: Perempuan Korban Belum Mendapat Perlindungan Komprehensif."

5 Syafaat Muhammad, "Fenomena Cerai Gugat Di Kabupaten Kuningan: Sebuah Kajian Perubahan Sosial Dalam Masyarakat Dan Keluarga," Jurnal Bimas Islam 9, no. IV (2016): 603.

6 "Cerai Gugat 59 Persen, Ekonomi Syariah 0,01 Persen Diunduh Dari Pada Senin," Badan Peradilan Agama, accessed March 24, 2015, http://badilag.net/seputar-ditjen-badilag/seputar-ditjenbadilag/cerai-gugat-59-persen-ekonomi-syariah-001persen-34.
}

menjadi pelaku maupun korban KDRT untuk ditumbuhkan sejak dini dan keasadaran ini perlu disosialisasikan kepada masyarakat seluas-luasnya.

KDRT muncul akibat relasi yang tidak setara antara pelaku dan korban dalam sebuah rumah tangga. Misalnya dalam relasi suami dan istri, orang tua dan anak, juga pengguna jasa dan pekerja rumah tangga. Relasi ini sebenarnya tidak tetap atau terus berubah seiring dengan perubahan yang selalu terjadi di sepanjang usia sebuah rumah tangga. Namun pada prinsipnya, relasi yang tidak setara akan menyebabkan pihak yang lebih kuat mempunyai kecenderungan sebagai pelaku dengan pihak yang lebih lemah sebagai korban. Misalnya dalam relasi suami-istri pada umumnya pihak yang kuat secara fisik dan ekonomi adalah suami, maka pelaku kekerasan dalam relasi ini kecenderungan besarnya adalah suami dengan istri sebagai korban. Namun demikian, dalam konteks tertentu di mana istri mempunyai daya tawar yang lebih tinggi daripada suami, misalnya istri lebih kaya, pendidikan lebih tinggi, dari keluarga yang lebih terpandang, dan lain-lain, maka istri sangat mungkin berbalik menjadi pelaku kekerasan dengan suami sebagai korban. Demikian pula halnya ketika anak memasuki usia dewasa, secara ekonomi semakin mapan, nama mulai terkenal sedangkan orang tuanya berasal dari keluarga miskin, secara fisik semakin renta, maka anak bisa berbalik pula mempunyai kecenderungan besar untuk melakukan kekerasan pada orang tua.

KDRT dipicu oleh banyak faktor seperti ideologi atau pandangan dunia sebuah masyarakat yang kemudian berpengaruh pada cara pandang dan prilaku politik, ekonomi, sosial, budaya termasuk tafsir agama (bukan agamanya itu sendiri). Salah satunya adalah ideologi patriarki yang kemudian memengaruhi cara pandang dan prilaku dalam kehidupan personal, rumah tangga, masyarakat, negara, bahkan tatanan kehidupan global. Ideologi patriarki adalah sebuah cara pandang yang menempatkan laki-laki sebagai pusat kehidupan sehingga mendudukkan laki-laki dalam posisi yang lebih tinggi daripada perempuan, 
bahkan satu-satunya yang tinggi. Ideologi ini dapat ditemukan di berbagai masyarakat dan negara, baik pada masa lampau maupun pada masa kini. Ideologi ini sebagai pandangan dunia bisa mempengaruhi berbagai sendi kehidupan. Ia bisa menyelinap dalam struktur bahasa, ungkapan-ungkapan khas daerah, maupun prilaku budaya lainnya. Misalnya ungkapan perempuan sebagai konco wingking (teman di belakang) bagi laki-laki yang dimiliki oleh masyarakat Jawa. Ideologi patriarkhi melahirkan diskriminasi gender atau diskriminasi atas dasar penyikapan berbeda pada laki-laki dan perempuan. pengaruh ideologi ini pada kebijakan misalnya ditunjukkan oleh adanya 342 kebijakan yang mengandung diskriminasi gender sejak bergulirnya kebijakan otonomi daerah pada tahun 1999 sampai dengan 18 Agustus 2013 yang ditemukan oleh Komnas Perempuan. ${ }^{7}$

Ideologi patriarkhi juga bisa mempengaruhi tafsir agama sehingga melahirkan tafsir agama yang bias gender yang kerap dijadikan pula sebagai legitimasi atas prilaku kekerasan dalam rumah tangga atas nama Islam. Padahal pada masa kehadirannya, spirit penghapusan KDRT dalam Islam sesungguhnya sangat kuat.

\section{Spirit Penghapusan KDRT dalam Islam}

Masyarakat Arab pada masa kehadiran Islam adalah sebuah masyarakat dengan ideologi patriarkhi yang sangat kuat. Mereka menempatkan perempuan dalam posisi yang sangat rendah. Yusuf al-Qaradlawi menggambarkan kondisi perempuan saat itu sebagai berikut:

Ketika itu perempuan diperjualbelikan seperti hewan dan barang. Mereka dipaksa untuk kawin dan melacur. Mereka diwariskan namun tidak mewarisi, dimiliki namun tidak memiliki, dan perempuan yang memi-

\footnotetext{
7 "Siaran Pers Komnas Perempuan: Kebijakan Diskriminatif Yang Bertentangan Dengan Konstitusi," Komnas Perempuan, 2013, https://www.komnasperempuan.go.id/siaran-pers-komnas-perempuankebijakan-diskriminatif-yang-bertentangan-dengankonstitusi/.
}

liki sesuatu dihalangi untuk menggunakan apa yang dimilikinya kecuali dengan izin laki-laki. Suami mempunyai hak untuk menggunakan hartanya tanpa persetujuan isteri. Kaum laki-laki di banyak negeri berbeda pendapat tentang hakikat perempuan apakah ia seorang manusia yang mempunyai jiwa dan ruh yang kekal seperti pria atau tidak? Apakah ia beragama dan sah ibadahnya atau tidak? Apakah ia nanti masuk surga atau masuk neraka? Salah satu konsili di Roma menetapkan bahwa perempuan adalah hewan najis yang tidak mempunyai ruh dan kekekalan, namun ia wajib beribadah dan berkhidmah agar mulutnya dibungkam seperti sapi dan anjing peliharaan untuk mencegahnya tertawa dan berbicara, karena ia adalah alat penggoda setan. Salah satu undang-undang membolehkan orangtua menjual anak perempuannya. Sebagian orang Arab berpendapat seorang bapak mempunyai hak untuk mengubur anak perempuannya hidup-hidup. Di antara mereka pun ada yang berpendapat bahwa seorang laki-laki tidak dihukum qishas dan tidak perlu membayar diyat jika membunuh seorang perempuan. $^{8}$

Hal serupa dikemukakan oleh Haekal, seorang sejarawan Islam, sebagai berikut:

Pada jaman jahiliyah orang-orang Arab itu belum mengenal arti suatu organisasi yang tetap, selain apa yang sudah berjalan menurut adat istiadat. Mereka tidak punya suatu ketentuan keluarga, suatu undangundang perkawinan dan syarat-syarat perceraian. Pada dasarnya hubungan pria dan perempuan dalam masyarakat Arab itu seluruhnya -berdasarkan bukti-bukti alQur'an serta peninggalan-peninggalan sejarah masa itu- tidak lebih adalah suatu hubungan jantan dengan betina, dengan sedikit perbedaan, sesuai dengan tingkat-tingkat kelompok dan golongan-golongan kabilah masing-masing yang pada umumnya tidak

\footnotetext{
${ }^{8}$ Yusuf Qardhawi, Berinteraksi Dengan Al-Qur'an, Penerjemah Abdul Hayyie Al-Kattani (Jakarta: Gema Insani Press, 1999), 151-152.
} 
jauh dari cara hidup yang masih miripmirip dengan tingkatan manusia primitif juga pada masa itu masalah poligami dan perbudakan adalah tanpa ada batas atau sesuatu ikatan. Laki-laki boleh kawin sesukanya, boleh mengambil gundik sesukanya. Mereka semua boleh saja beranak sesuka-sukanya... ${ }^{9}$

Ibnu Taimiyah mengatakan bahwa kebencian masyarakat Arab terhadap perempuan itu paling tinggi dibandingkan dengan kebencian pada lainnya. ${ }^{10}$ Dalam sebuah sistem sosial dan budaya seperti ini, maka perempuan sangat rentan mengalami KDRT bahkan sejak pertama kali menghirup udara di dunia, yaitu dikuburkan hidup-hidup begitu lahir sebagaimana tersurat dalam Qs. an-Nahl/19:58-59 sebagai berikut:

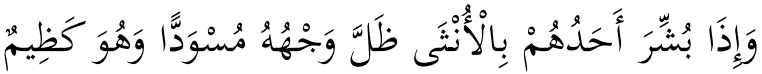

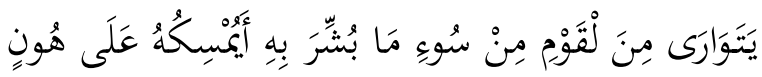

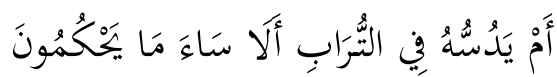

Dan apabila seseorang dari mereka diberi kabar dengan (kelahiran) anak perempuan, hitamlah (merah padamlah) mukanya, dan dia sangat marah.Ia menyembunyikan dirinya dari orang banyak, disebabkan buruknya berita yang disampaikan kepadanya. Apakah dia akan memeliharanya dengan menanggung kehinaan ataukah akan menguburkannya ke dalam tanah (hiduphidup)? Ketahuilah, alangkah buruknya apa yang mereka tetapkan itu.

Muhammad Quraish Shihab menjelaskan tiga hal yang menjadi alasan masyarakat Arab membunuh bayi perempuan hidup-hidup. Pertama, khawatir jatuhnya orangtua pada lembah kemiskinan dengan menanggung biaya hidup anak-anak perempuan yang lahir karena

\footnotetext{
9 Muhammad Husain Haekal, Sejarah Hidup Muhammad, Penerjemah Ali Audah (Bandung: Dunia Pustaka Jaya, 1979), 395-397.

10 Al-Harani Abu al-'Abbas Ahmad bin Abd alHalim bin Taimiyyah, Al-Nubuwwat, jilid 1. (Mesir: alMathba'ah al-Salafiyyah, 1378 H), 240.
}

menurut mereka anak perempuan tidak produktif. Kedua, khawatir jatuhnya anak pada lembah kemiskinan jika mereka dewasa kelak. Ketiga, khawatir menanggung aib akibat anak perempuan mereka ditawan dalam peperangan sehingga diperkosa atau karena terjadi perzinaan. $^{11}$

Setelah selamat dari upaya pembunuhan ketika lahir, seorang perempuan rentan mengalami kekerasan di usia dewasa seperti diwariskan sebagaimana harta. Hal ini diisyaratkan oleh al-Qur'an surat an-Nisa/4:19 sebagai berikut:

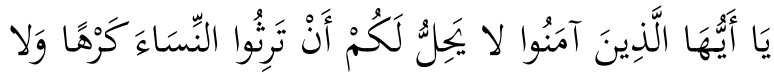

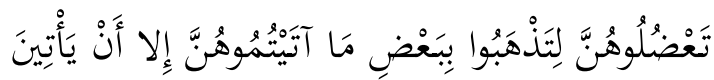

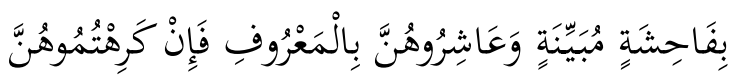

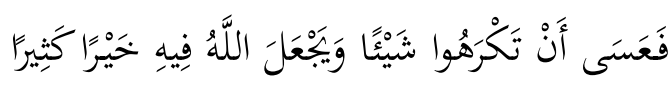

Wahai orang-orang yang beriman, tidak halal (haram) bagi kamu mempusakai (mewarisi) perempuan dengan paksaan, dan janganlah kamu menyusahkan mereka (para perempuan) karena hendak mengambil kembali sebagian (mahar/maskawin) dari apa yang telah kamu (para suami) berikan kepadanya (kepada para isterimu), kecuali apabila mereka (para isterimu) melakukan perbuatan keji yang nyata (yaitu berzina). Dan bergaullah dengan mereka (para isterimu) secara patut (dengan baik). Kemudian jika kamu (para suami) tidak menyukai mereka (para isteri) (maka bersabarlah), karena boleh jadi kamu sekalian tidak menyukai (membenci) sesuatu, padahal Allah menjadikan banyak kebaikan di dalamnya (di dalam sesuatu yang tidak kamu sukai/benci).

Ibnu Katsir dalam Tafsir al-Qur'an alAdhim mengutip hadis tentang prilaku masyarakat Arab pada perempuan yang ditinggal mati suaminya sebagai berikut:

11 M. Qurais Shihab, Tafsir Al-Misbah, Jilid 6 (Jakarta: Lentera Hati, 2009), 622-623. 


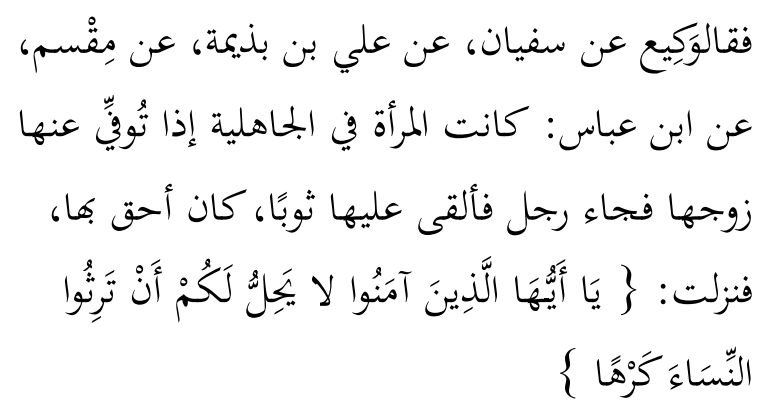

Diriwayatkan oleh Waki' dari Sufyan dari Ali bin Badzimah dari Miqsam Abdullah bin Abbas: "Bahwa dahulu perempuan (seorang isteri) di zaman Jahiliyyah kalau ditinggal mati suaminya, lalu datang seorang lelaki melemparkan kain/pakaian kepadanya (isteri yang ditinggal mati suaminya), maka dia (seorang lelaki yang melemparkan kain kepada seorang isteri yang ditinggal mati oleh suaminya)lah yang lebih berhak terhadap diri perempuan (isteri yang ditinggal mati suaminya) itu. ${ }^{12}$

Senada dengan riwayat di atas, ath-Thabari menjelaskan bahwa ayat tersebut turun terkaitdengan tradisi masyarakat Arab kala itu di mana jika seorang perempuan yang ditinggal mati suaminya, maka anaknya atau kerabatnya lebih berhak atas diri perempuan itu daripada siapa pun termasuk diri perempuan itu sendiri. Merekalah yang memutuskan apakah perempuan tersebut akan dinikahinya, dinikahkan dengan orang lain, atau bahkan dilarang menikah sepanjang hidupnya. ${ }^{13}$

Dalam sistem sosial dan budaya patriarki yang kuat seperti ini, maka perempuan menjadi rentan mengalami kekerasan di setiap tahap kehidupannya, baik di luar maupun di dalam rumah tangga. Berikut adalah beberapa di antaranya.

1. Perkawinan anak. Perempuan kerap dikawinkan, bahkan kemudian diceraikan sebelum mengalami menstruasi yang pertama sebagaimana diisyaratkan oleh adanya aturan tentang iddahnya perempuan

12 Imaduddin Abul Fida' Ibnu Katsir, Tafsir AlQur'ān Al-'Aẓim, Juz. 2 (Kairo: Darul Kutub alMisriyah, 1988), 239.

13 Abu Ja'far Muhammad bin Jarir bin Yazid bin Ghalib At-Thabari, Jami' L-Bayan Fi Ta'wil Al-Qur'an, jilid 3 (t.k.: Muassasah ar-Risalah, 2000), 646. yang belum mengalami menstruasi pada Qs. al-Thalaq/65:4.

2. Perkawinan paksa. Anak perempuan dipaksa kawin dengan seorang lelaki yang tidak kenal demi kepentingan orangtuanya sebagaimana diisyaratkan oleh beberapa hadis shahih tentang perintah meminta ijin pada perempuan yang akan dinikahkan, baik gadis maupun janda sebagai berikut:

Dari Abi Salamah sesungguhnya Abu Hurairah menceritakan bahwasanya Nabi Saw. bersabda: "Tidak dinikahi seorang janda sehingga ia dimintai pendapatnya dan tidak dinikahi seorang gadis kecuali dimintai izinnya." Para sahabat kemudian bertanya: "Bagaimana ijinnya (anak gadis)??." Rasulullah pun menjawab: "Diamnya." (HR. Bukhari). ${ }^{14}$

3. Perceraian dan rujuk berulang-ulang tanpa batas. Pada masa jahiliyah seorang suami bisa mencerai dan merujuk istrinya kembali sebanyak berkali-kali tanpa batas sebagaimana diisyaratkan oleh pembatasan thalaq yang boleh diruju' sebanyak dua kali pada Qs. al-Baqarah/2:229.

4. Poligami dengan jumlah istri tidak terbatas. Seorang suami pada masa Jahiliyah bisa mempunyai istri banyak dengan jumlah tanpa batas sebagaimana diisyaratkan pada surat an-Nisa/4:3 yang membatasi hanya sampai empat dan mendorong untuk monogami, juga informasi-informasi sejarah.

5. Penelantaran nafkah. Seorang laki-laki terutama yang mempunyai banyak istri kerap menelantarkan nafkah istri dan anakanaknya. Hal ini terjadi bisa karena tidak mampu, bisa pula karena tidak mau, sebagaimana diisyaratkan dalam alNisa/4:129 yang melarang membuat istri terkatung-katung.

6. Status gantung, yakni tidak dinafkahi namun juga tidak diceraikan sehingga tidak bisa menikah dengan laki-laki lain sebagaimana diisyaratkan oleh an-

${ }^{14}$ Muhammad bin Ismail bin Ibrahim Al-Bukhari, Shahih Al-Bukhari, Juz 16 (t.k.: Maktabah Syamilah, t.t.), 100 . 
Nisa/4:129 sebagai akibat penelantaran nafkah lahir maupun batin.

7. Diwariskan sebagaimana harta ketika suaminya mati sebagaimana tersirat dalam Qs. an-Nisa 4/19 yang melarang mewarisan perempuan apalagi dengan cara paksa.
Islam merespon kekerasan terhadap perempuan baik yang terjadi di luar maupun di dalam rumah tangga mulai dengan cara evolusioner hingga revolusioner sebagaimana ditunjukkan oleh tabel 2 berikut:

Tabel. 2

Respon Islam atas Kekerasan terhadap Perempuan di luar dan di dalam Rumah Tangga NO PRA ISLAM (JAHILIYYAH) ISLAM

\begin{tabular}{lll}
\hline 1 & Diragukan status kemanusiaannya. & Dipastikan status kemanusiaannya \\
\hline 2 & Diragukan bisa mendapat pahala & Dipastikan bisa \\
\hline 3 & Diragukan bisa masuk surga & Dipastikan bisa \\
\hline 4 & Dilacurkan & Dilarang keras \\
\hline 5 & Dihadiahkan & Dilarang keras \\
\hline 6 & Dijadikan jaminan hutang & Dilarang keras \\
\hline 8 & Dijadikan jamuan (gratifikasi seks) & Dilarang keras \\
\hline 9 & Dikuburkan hidup-hidup ketika lahir & Dilarang keras \\
\hline 10 & Dikawinkan ketika anak-anak & Diabadikan namanya pada nama anak \\
\hline 11 & Dipaksa kawin & Disyaratkan baligh \\
\hline 12 & Tidak berhak atas mahar & Diharuskan izinnya \\
\hline 13 & Diperbudak secara seksual oleh suami & Diberi hak mutlak atas mahar \\
& & $\begin{array}{l}\text { Diperintahkan untuk diperlakukan dengan } \\
\text { layak (muasyarah bil ma'ruf) }\end{array}$ \\
\hline 14 & Dipukul sesuka hati & Dilarang main pukul \\
\hline 15 & Diperintahkan taat suami secara mutlak & $\begin{array}{l}\text { Suami dan istri diperintahkan taat secara } \\
\text { mutlak hanya pada Allah. }\end{array}$ \\
\hline 16 & Dipoligami tanpa batas & Dibatasi 4 dan didorong monogami \\
\hline 17 & Dicerai dan rujuk tanpa batas & Dibatasi hanya 2 kali \\
\hline 18 & Dituduh zina dan dihukum tanpa proses & $\begin{array}{l}\text { Dijamin haknya untuk menolak tuduhan } \\
\text { melalui sumpah Li'an }\end{array}$ \\
\hline 19 & Status gantung (muallaqah) & Dilarang \\
\hline 20 & Ditelantarkan nafkahnya & Diwajibkan untuk dinafkahi \\
\hline 21 & Diwariskan & $\begin{array}{l}\text { Dilarang, bahkan diberi hak untuk mewarisi } \\
\text { dan mewariskan harta }\end{array}$ \\
\hline 22 & Dikenai sumpah dzihar & Suami diberi kafarat \\
\hline & &
\end{tabular}

Tabel di atas menunjukkan bahwa Islam melakukan tindakan sangat revolusioner atas budaya patriarkhi masyarakat Arab dan tentu saja budaya patriarkhi di mana pun berada yang menistakan perempuan. Dalam sebuah riwayat Imam Bukhari, Umar bin Khattab memberikan kesaksian atas perubahan drastis yang terjadi pada dirinya dan masyarakat Arab dalam memandang dan menyikapi perempuan sebagai berikut:

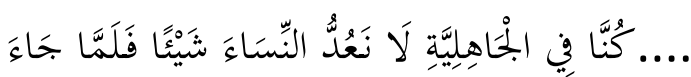

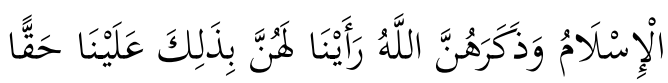

....Dulu kami pada masa Jahiliyah sama sekali tidak pernah memperhitungkan perempuan. Kemudian ketika Islam datang dan Allah menyebut mereka (dalam alQur'an), barulah kami sadar mereka 
mempunyai hak atas kami...."(HR. Bukhari) $^{15}$

Tindakan Islam dalam mengubah cara pandang dan cara bersikap masyarakat Arab pada perempuan terbilang radikal. Pemberdayaan perempuan menjadi salah satu topik yang sangat menonjol dalam al-Qur'an. Perempuan bahkan diabadikan sebagai salah satu mana surat ke-empat yaitu an-Nisa. Yusuf al-Qaradlawi mengatakan bahwa di antara topik terpenting yang dibawa al-Qur'an berkaitan dengan perkawinan adalah perintah untuk berlaku adil pada perempuan, membebaskannya dari kezaliman jahiliyyah, dan dari tindakan otoriter suami dalam menentukan kehidupannya. Al-Qur'an memberikan kehormatan pada perempuan baik sebagai anak, isteri, ibu maupun sebagai anggota masyarakat. $^{16}$

Cara pandang dan sikap baru yang menempatkan perempuan dan laki-laki dalam posisi yang sejajar ini masih sulit diterima di masa modern sekarang ini. Apalagi pada masa Rasulullah Saw hidup atau lebih dari 1400 tahun lalu sehingga bukan kebetulan jika Qs at-Taubah/9:71 menegaskan bahwa hanya laki-laki dan perempuan berimanlah yang bisa menerima dan menempatkan diri secara sejajar dan saling bekerjasama melaksanakan kewajiban kepada Allah dan kepada umat manusia, sebagai berikut:

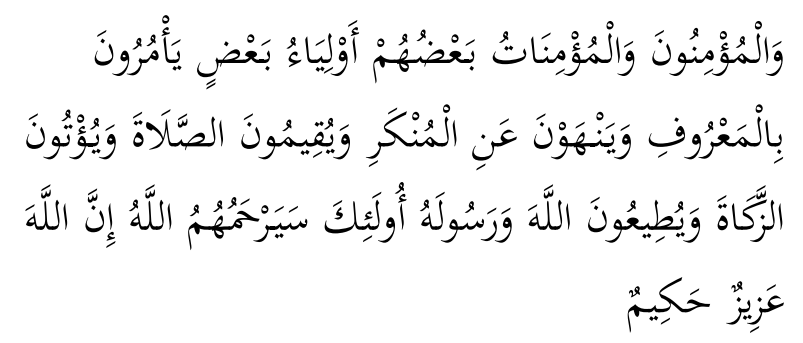

Dan orang-orang yang beriman, lelaki dan perempuan, sebagian mereka (adalah) menjadi penolong bagi sebagian yang lain. Mereka menyuruh (mengerjakan) yang makruf, mencegah dari yang mungkar,

15 Al-Bukhari, Shahih Al-Bukhari, 170. Ibnu Hajar Asqalani, Fathul Bārī, Juz 11 (Beirut: Dar al-Fikr, 2005), 484.

${ }^{16}$ Qardhawi, Berinteraksi Dengan Al-Qur'an, 148. mendirikan sembahyang, menunaikan zakat, dan mereka taat kepada Allah dan Rasul-Nya. Mereka itu akan diberi rahmat oleh Allah; sesungguhnya Allah Maha Perkasa lagi Maha Bijaksana.

Salah satu sebab penting mengapa menempatkan perempuan di posisi yang sejajar dengan laki-laki itu sulit dan mengapa membangun budaya kerjasama antara perempuan dan laki-laki itu susah adalah kuatnya budaya patriarkhi di tempat asal munculnya Islam yang terjalin berkelindan dengan kuatnya budaya patriarkhi di tempat-tempat Islam menyebar di kemudian hari. Dampaknya adalah meskipun spirit penghapusan KDRT dalam Islam begitu kuat, namun pergulatan ajaran Islam dengan budaya patriarkhi di berbagai tempat khususnya setelah wafatnya Rasulullah Saw menyebabkan spirit Islam dalam penghapusan KDRT itu menjadi kabur, bahkan tidak jarang ajaran Islam justru dijadikan legitimasi atas tindakan KDRT. Pemahaman atas Islam yang bias gender menjadi lebih kuat dan populer daripada pemahaman atas Islam yang adil gender. Misalnya pemahaman atas Islam sebagai berikut:

1. Pemahaman atas Islam tentang bolehnya poligami lebih kuat dan populer daripada keharusan mewujudkan keadilan dalam kehidupan perkawinan dan dorongan untuk monogami,

2. Pemahaman Islam tentang bolehnya pemukulan istri lebih kuat dan populer daripada keharusan memperlakukan istri dengan layak (musyarah bil-ma'ruf),

3. Pemahaman atas Islam tentang bolehnya perkawinan paksa lebih kuat dan populer daripada keharusan meminta ijin perempuan yang akan dinikahkan baik gadis maupun janda,

4. Pemahaman atas Islam tentang bolehnya melakukan pemaksaan suami untuk berhubungan seskual dengan istri lebih kuat dan populer daripada keharusan untuk memperlakukan istri dengan layak (musayarah bil ma'ruf) dan perintah untuk memperlakukan istri secara setara 
(diibaratkan sebagai pakaian satu sama lain) dalam hubungan seksual.

\section{Mengembalikan Spirit Islam dalam Menghapus KDRT.}

Akar terjadinya KDRT adalah adanya relasi yang timpang dalam keluarga, baik antara suami dan istri, maupun antara anak dan keluarga. Dalam Islam relasi orang tua-anak diatur melalui konsep wilayah (perwalian) dan relasi antara suami-istri melalui konsep qiwamah (kepemimpinan dalam keluarga). Dua konsep kunci ini sama-sama memberikan kewajiban pada laki-laki, yaitu ayah dalam wilayah dan suami dalam qiwamah, untuk memberikan perlindungan dan pertanggungjawaban atas perempuan, yaitu anak perem-

puan dalam wilayah dan istri dalam qiwamah. Perkawinan merupakan momen perpindahan kewajiban untuk melindungi dan bertanggungjawab atas perempuan dari ayah sebagai wali kepada calon suami sebagai kepala keluarga. Oleh karenanya, pihak-pihak yang melakukan ijab kabul dalam perkawinan Islam bukanlah calon suami dan istri melainkan antara ayah calon istri dan si calon suami.

Konsep Qiwamah dan Wilayah mempunyai konsep turunan yang cukup banyak baik terkait dengan relasi laki-laki dan perempuan sebelum menikah, masa peralihan, masa nikah, maupun setelah nikah berakhir. Misalnya konsep-konsep seperti dalam tabel 3 berikut ini:

Tabel.3

Beberapa Konsep Turunan Wilayah dan Qiwamah

\begin{tabular}{llll}
\hline PRA & PERALIHAN & NIKAH & PASCA \\
\hline Baligh & Wali & Kepala keluarga & Thalaq \\
\hline Kafaah & Saksi & Nafkah & Ruju' \\
\hline Taaruf & Penghulu & Jima' & Khulu' \\
\hline Khitbah & Mahar & Hamil & Iddah \\
\hline Izin menikah & Akad & Wiladah & Ihdad \\
\hline Mahram & Walimah & Nifas & Waris \\
\hline Nasab & Dll & Rodlo'ah & Mut'ah \\
\hline Dll & & Hadlonah & Hadlonah \\
\hline & & Dll & Dll
\end{tabular}

Untuk melakukan tugas sebagai wali dan kepala keluarga atas perempuan, lelaki memerlukan wewenang, yaitu wewenang untuk melakukan tanggungjawab dan perlindungan atas perempuan.Dalam menjalankan fungsi sebagai wali dan kepala keluarga, seorang ayah dan suami antara lain bertanggungjawab untuk untuk memberikan nafkah pada perempuan dan melindungi merekadari segala gangguan keamanan, baik di dalam rumah, apalagi ketika keluar rumah (mahram), dan seorang ayah berkewajiban untuk memastikan bahwa calon suami anak perempuannya adalah orang yang bertanggungjawab (wali mujbir). Dengan kewajibannya tersebut kemudian ayah dan suami mempunyai hakhak istimewa. Misalnya bagian waris yang lebih besar daripada perempuan, melakukan poligami dalam rangka memberikan perlin- dungan dan tanggungjawab pada perempuan, diberi kepercayaan khusus sebagai mahram, dan menjadi wali dalam perkawinan anaknya, dan lain-lain.

Persoalan kemudian muncul ketika wewenang sebagai wali dan kepala keluarga yang dimiliki laki-laki ini digunakan tanpa ruh perlindungan dan pertanggungjawaban sehingga wewenang kemudian berubah menjadi kesewenang-wenangan sehingga terjadi kekerasan dalam rumah tangga. Ayah dan suami yang seharusnya melindungi perempuan dari kekerasan yang dilakukan orang lain malah melakukannya sendiri. Misalnya memaksan anak kawin, melarang istri bekerja atau mengijinkan istri bekerja namun suami yang menguasai gajinya, memutus tali silaturahmi perempuan dengan keluarganya, memukul, 
bahkan melakukan perkosaan incest pada anak perempuannya.

Persoalan lainnya muncul juga muncul akibat pembakuan peran laki-laki dalam rumah tangga sehingga laki-laki tetap mendapat hak-hak istimewanya sebagai wali maupun kepala keluarga meskipun ketika mereka tidak melakukan fungsi perlindungan dan pertanggungjawaban. Sementara perempuan tetap tidak memperoleh hak-hak istimewa sebagai wali dan kepala keluarga meskipun ketika mereka menjalankan peran sebagai wali dan kepala keluarga atas rumah tangga mereka. Misalnya adalah dua kasus berikut ini:

1. Seorang istri ditinggalkan suaminya sejak hamil lalu melahirkan seorang bayi perempuan. Bayi ini tumbuh dan dibesarkan seorang diri oleh ibunya. Ayahnya tidak pernah berusaha menemui dan tidak memberikan nafkah sepeser pun hingga anak dewasa. Ketika mau menikah, ayahnya tetap dicari untuk menjadi wali nikah bagi anaknya. Sementara itu, ibunya yang membesarkan anak seorang diri tidak diberi hak untuk menjadi wali anaknya. Bahkan di sebuah desa di Jawa Barat terjadi kasus di mana ayah melakukan perkosaan incest pada anak perempuannya. Kemudian ayah di penjara. Ketika anak perempuan itu mau menikah, ijin tertulis dari ayahnya tetap diharuskan ada. Sementara ayah menolak memberikan ijin.

2. Seorang anak perempuan sulung memutuskan untuk berhenti sekolah karena orangtuanya sakit-sakitan dan demi adik laki-lakinya bisa sekolah. Ia bekerja keras sambil merasa orangtuanya yang sakit dan menyekolahkan adik laki-lakinya hingga lulus perguruan tinggi tidak seperti dirinya. Begitu orangtuanya meninggal ia mendapatkan waris harta orangtuanya yang ia rawat sendiri hanya separo dari adik laki-laki yang ia biayai pendidikannya hingga menjadi sarjana dan mendapatkan pekerjaan yang lebih bagus darinya.

3. Seorang istri yang mempunyai bayi lakilaki ditinggal mati oleh suaminya. Ialah yang akan menjadi penanggungjawab tunggal untuk membesarkan sendiri bayi laki-laki tersebut sebagaimana terjadi di masyarakat modern pada umumnya. Ia pun hanya mendapatkan 1/8 harta warisan suaminya, sedangkan bayi laki-laki yang akan dia besarkanmendapatkan ashabah atau sisanya yaitu $7 / 8$.

Perubahan sosial menyebabkan banyak pergeseran sehingga perempuan telah mampu menempuh pendidikan formal tertinggi dan juga mencapai puncak karirnya. Mereka telah pula terjun secara profesional di lembagalembaga tinggi pemerintahan mau pun swasta. Sebaliknya, tidak semua laki-laki mampu dan mempunyai kesempatan untuk bergerak maju sesuai perkembangan zaman. Hal ini menyebabkan laki-laki (ayah atau suami) secara ekonomi, sosial, politik, bahkan agama tidak selalu lebih kuat daripada perempuan sebagaimana diasumsikan dalam konsep wilayah dan qiwamah. Harapan masyarakat yang tinggi pada laki-laki sebagai pencari nafkah keluarga menjadi bumerang bagi laki-laki yang tidak mampu memenuhinya dan kadang membuat harga dirinya terusik sehingga terjadilah kekerasan dalam rumah tangga. Sementara perempuan yang terus dididik bahwa ia akan dinafkahi oleh suaminya tetapi dalam kenyataannya justru dia yang menafkahi juga menjadi kecewa karena tidak siap mental.

Salah satu strategi dalam membangun keluarga sakinah pada masa sekarang adalah dengan memahami konsep keluarga sakinah dalam perspektif kesetaraan. Laki-laki dan perempuan perlu dibangun kesadaran untuk bekerjasama memenuhi kebutuhan keluarga dan berbagi peran secara fleksibel di mana pada prinsipnya siapa pun yang lebih kuat dalam satu hal (bisa laki-laki, bisa pula perempuan), maka ia bertanggungjawab atas pihak lainnya yang dalam hal tersebut lebih lemah (bisa laki-laki, bisa pula perempuan), keduanya siap berbagi tugas secara fleksibel baik di dalam maupun di luar rumah tangga.

Keluarga sakinah perspektif kesetaraan dibangun di atas nilai-nilai kesetaraan Islam sebagai berikut:

1. Laki-laki dan perempuan adalah samasama kedudukannya sebagai hamba Allah 
dan khalifah di muka bumi (AdzDzariyat/51:56, al-Ahzab/33:72),

2. Laki-laki dan perempuan diciptakan dari bahan dan melalui proses yang sama (alMu'minun/ 23:12-16),

3. Nilai manusia tidak ditentukan oleh jenis kelamin, melainkan oleh ketaqwaan (alHujurat/49:13).

4. Laki-laki dan perempuan yang berbuat baik sama-sama akan masuk sorga dan sebaliknya (Al-Nisa'/4:124),

5. Laki-laki dan perempuan menjadi pelindung satu sama lain (at-Taubah/9:71).

6. Laki-laki dan perempuan akan kembali pada Allah sebagai dirinya sendiri (alAn'am/6:94).

Berdasarkan konsep dasar tersebut, maka perkawinan dipahami tidak sebatas penghalalan hubungan seksual melainkan ikatan tanggungjawab atas segala konsekuensi dari hubungan seksual tersebut, baik secara fisik maupun secara psikhis sehingga perkawinan dipandang sebagai berikut:

1. Janji yang kokoh: laki-laki dan perempuan tidak boleh mempermainkan perkawinan. (an-Nisa/4: 20-21):

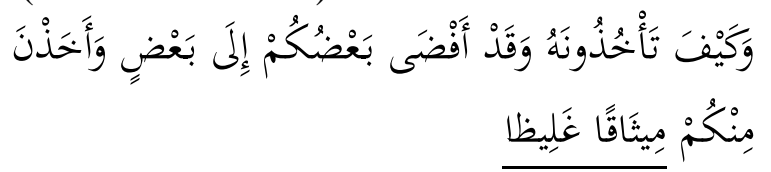

2. Nikah mempunyai komitmen ganda: horisontal yaitu antara manusia dan vertikal antara keduanya dengan Allah, sebagaimana ditegaskan oleh Rasulullah dalam pidato di Haji Wada:

Bertaqwalah kalian semua kepada Allah dalam memperlakukan para istri. Sesungguhnya kalian telah meminang mereka dengan amanah dari Allah dan menghalalkan farji mereka dengan kalimat Allah. (HR. Muslim). ${ }^{17}$

3. Untuk memperoleh ketenangan melalui hubungan yang didasarkan atas cinta kasih, bukan kekuasaan (ar-Rum/30:21)

17 Abul Husain bin al-Hajjaj bin Muslim, Shahih Muslim, Juz 6 (t.k.: Maktabah Syamilah, t.t.), 245.

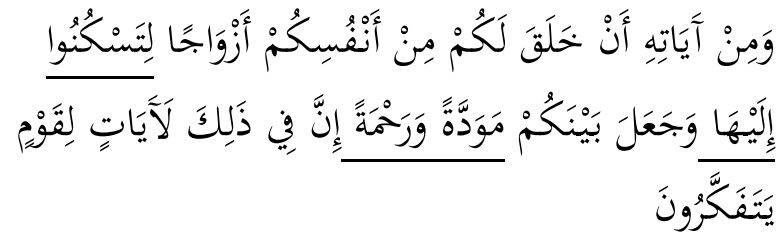

Relasi suami-istri dan orangtua anak dalam sebuah rumah tangga didasarkan pada prinsipprinsip sebagai berikut:

1. Al-qiyam bi hududillah/ berdasarkan ketentuan Allah, bukan kemauan salah satu pihak (QS. 2:229, 230),

2. Ridlo/ dikehendaki dan disadari oleh kedua belah pihak (QS. 2:232, 233, QS. 4:24) (tidak ada pemaksaan dalam perkawinan),

3. Ma'ruf/layak (QS. 2:180, 228, 229, 231, 232, 233, 234, 235, 236, 240, 241, QS. 4:19, 25, QS. 65:2, 6), (tidak boleh sewenang-wenang)

4. Ihsan/menciptakan kondisi lebih baik (QS. 2:229, QS. 6:151)

5. Nihlah/ tulus (QS. 4:4): tidak boleh merendahkan karena support ekonomi yang diberikan pada keluarga,

6. Musyawarah(QS. 2:233): tidak boleh sewenang-wenang memberi keputusan dalam keluarga secara sepihak.

7. Ishlah/ perdamaian (QS. 2:228, QS. 4:35, 128): problem tidak boleh diselesaikan dengan kekerasan.

Pencegahan KDRT dapat dilakukan dengan memulai membangun kembali prinsip berumah tangga dalam perspektif kesetaraan yang telah diperkenalkan Islam sejak lebih dari 1400 tahun lalu. Jika prinsip-prinsip ini sulit diterapkan pada masa kini, maka hal ini hanya menunjukkan bahwa tantangan patriarkhi memang masih besar hingga kini. Bahkan tantangan yang lebih besar lagi adalah karena ideologi patriarkhi tersebut kini telah banyak berbalut ajaran Islam.

\section{SIMPULAN}

Salah satu misi utama yang dibawa oleh setiap Rasul Allah adalah mengesakan Allah sebagai Tuhan semesta Alam yang terjalin berkelindan dengan prinsip kesetaraaan 
manusia sebagai sesama hamba Allah dan khalifah di muka bumi. Misi ini meniscayakan sikap memanusiakan manusia atau memperlakukan manusia secara manusiawi sehingga panggung sejarah para Rasul ini selalu diwarnai dengan perseteruan dengan para pembesar kaum (al-Mala') yang dirugikan oleh ajaran mereka.

Kekerasan atas manusia berbasis apapun dan ruang domestik maupun publik pada dasarnya bertentangan dengan misi utama ajaran Allah. Demikian halnya kekerasan dalam rumah tangga. Rasulullah Muhammad Saw sepanjang masa kerasulan beliau terus bergulat dengan problem-problem kemanusiaan. Salah satu problem yang mendapatkan perhatian khusus adalah KDRT. Perlakuan tidak manusiawi masyarakat Arab pada perempuan di ruang publik kala itu, berkorelasi langsung dengan perlakuan serupa di ranah rumah tangga. Beberapa bentuk KDRT langsung dihapus seketika seperti larangan mengubur bayi perempuan, larangan mewariskan dan mengawini ibu kandung, saudari kandung, bibi, namun sebagian lainnya dikompromikan karena situasinya belum memungkinkan untuk dihapus sekaligus. Sayang sekali, bentuk-bentuk kekerasan yang dikompromikan dan semestinya berlaku sementara ini justru kerap dijadikan justifikasi bagi prilaku KDRT.

\section{DAFTAR PUSTAKA}

Abu al-'Abbas Ahmad bin Abd al-Halim bin Taimiyyah, Al-Harani. Al-Nubuwwat. 1st ed. Mesir: al-Mathba'ah al-Salafiyyah, n.d.

Al-Bukhari, Muhammad bin Ismail bin Ibrahim. Shahih Al-Bukhari. Juz 16. t.k.: Maktabah Syamilah, n.d.

Alimat. Kisah Perjuangan Perempuan Dalam KeluargaAlimat, 2012. Jakarta: Alimat, 2012.

Asqalani, Ibnu Hajar. Fatḥul Bārī. Juz 11. Beirut: Dar al-Fikr, 2005.

At-Thabari, Abu Ja'far Muhammad bin Jarir bin Yazid bin Ghalib. Jami' L-Bayan Fi Ta'wil Al-Qur'an. Jilid 3. t.k.: Muassasah ar-Risalah, 2000.
Pergulatan spirit kuat anti KDRT dalam ajaran Islam dengan tradisi dan nilai-nilai patriarkhi di berbagai sistem kehidupan manusia khususnya masyarakat Muslim terus berlangsung hingga kini. Ajaran Islam juga terus ditafsirkan dan diimpelementasikan di ruang domestik maupun publik yang yang tentu saja melibatkan relasi gender, di samping juga relasi kuasa yang dinamis. Islam menolak keras segala bentuk KDRT sehingga justifikasi Islam atas KDRT yang diklaim sebagian pihak hanya menunjukkan bahwa nilai patriarkhi sedang lebih kuat daripada nilai Islam dalam pergulatan tersebut. Di sinilah perlunya tafsir alternatif atas Islam yang dijiwai oleh spirit anti kekerasan termasuk kekerasan berbasis gender yang melahirkan KDRT.

Membangun kesadaran tentang pentingnya keadilan gender atau keadilan pada laki-laki dan perempuan secara sekaligus, yang diiringi dengan merintis budaya ramah pada perempuan dan anak-anak, tradisi perkawinan dan rumah tangga dengan cara-cara yang bermartabat bagi kedua belah pihak, merupakan investasi besar bagi peradaban Islam yang adil dan bebas dari tindakan kekerasan sebagaimana dicita-citakan oleh Islam sejak kehadirannya. Ikhtiyar menghapus KDRT atas dasar apapun adalah misi profetik yang menjadi kewajiban setiap umat Rasul.

"Cerai Gugat 59 Persen, Ekonomi Syariah 0,01 Persen Diunduh Dari Pada Senin." Badan Peradilan Agama. Accessed March 24, 2015. http://badilag.net/seputar-ditjenbadilag/seputar-ditjen-badilag/ceraigugat-59-persen-ekonomi-syariah-001persen-34.

Haekal, Muhammad Husain. Sejarah Hidup Muhammad. Translated by Ali Audah. Bandung: Dunia Pustaka Jaya, 1979.

Ibnu Katsir, Imaduddin Abul Fida'. Tafsir AlQur'ān Al-'Azim. Juz. 2. Kairo: Darul Kutub al-Misriyah, 1988. 


\section{INTERNET}

"Lembar Fakta, Satu Dasawarsa UU PKDRT: Perempuan Korban Belum Mendapat Perlindungan Komprehensif." Jakarta, 2014.

https://www.komnasperempuan.go.id/wp -content/uploads/2014/09/LEMBAR-

FAKTA-Satu-Dasawarsa-UU-PKDRT-

Perempuan-Korban-Belum-Mendapat-

Perlindungan-Komprehensif.pdf.

"Lembar Fakta Catatan Tahunan (Catahu)

Komnas Perempuan Tahun 2014, ,

Kekerasan Terhadap Perempuan: Negara

Segera Putus Impunitas Pelaku.” Jakarta, 2015.

http://www.komnasperempuan.or.id/wpcontent/uploads/2015/03/Lembar-Fakta-

Catatan-Tahunan-CATAHU-Komnas-

Perempuan-Tahun-2014.pdf pada Senin 24 Maret 2015.

Muhammad, Syafaat. "Fenomena Cerai Gugat

Di Kabupaten Kuningan: Sebuah Kajian
Perubahan Sosial Dalam Masyarakat Dan Keluarga." Jurnal Bimas Islam 9, no. IV (2016): 599-640.

Muslim, Abul Husain bin al-Hajjaj bin. Shahih Muslim. Juz 6. t.k.: Maktabah Syamilah, n.d.

Qardhawi, Yusuf. Berinteraksi Dengan AlQur'an. Translated by Abdul Hayyie AlKattani. Jakarta: Gema Insani Press, 1999.

Shihab, M. Qurais. Tafsir Al-Misbah. Jilid 6. Jakarta: Lentera Hati, 2009.

"Siaran Pers Komnas Perempuan: Kebijakan Diskriminatif Yang Bertentangan Dengan Konstitusi." Komnas Perempuan, 2013. https://www.komnasperempuan.go.id/siar an-pers-komnas-perempuan-kebijakandiskriminatif-yang-bertentangan-dengankonstitusi/. 